
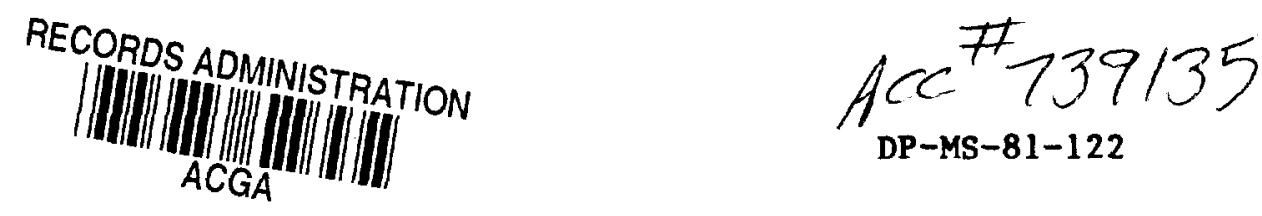

\title{
CHEMICAL DURABILITY OF GLASS CONTAINING SRP WASTE - LEACHABILITY CHARACTERISTICS, PROTECTIVE LAYER FORMATION, AND REPOSITORY SYSTEM INTERACTIONS
}

by

George G. Wicks, Barbara M. Robnett, and W. Duncan Rankin

E. I. du Pont de Nemours \& Co.

Savannah River Laboratory

Aiken, South Carolina 29808

Paper proposed for oral presentation at the

Fifth International Symposium on the Scientific

Basis for Radioactive Waste Management and for

publication in Volume 5 of the proceedings.

Berlin, (West) Germany

June $7-10,1982$

This paper was prepared in connection with work done under Contract No. DE-AC09-76SR00001 with the U.S. Department of Energy. By acceptance of this paper, the publisher and/or recipient acknowledges the U.S. Government's right to retain a nonexclusive, royalty-free license in and to any copyright covering this paper, along with the right to reproduce and to authorize others to reproduce all or part of the copyrighted paper. 
CHEMICAL DURABILITY OF GLASS CONTAINING SRP WASTE LEACHABILITT CHARACTERISTICS, PROTECTIVE LAYER FORMATION, AND REPOSITORY SYSTEM INTERACTIONS

GEORGE G. WICKS, BARBARA M. ROBNETT, AND W. DUNCAN RANKIN E. I. du Pont de Nemours \& Co. Savannah River Laboratory Aiken, South Carolina 29808

\section{LEACHABILITY AND FORMATION OF SURFACE LAYERS}

Leachability is one of the most important properties of solidified nuclear waste forms because it provides information on the performance and the subsequent safety and reliability that the waste products will possess. One of the most important experimental findings in the leachability field has been the discovery and subsequent detailed characterization of protective surface layers that form on waste glass during leaching. These layers can have a beneficial effect on product performance while in storage by improving product durability with time. As a result of surface layer formation and the effects on subsequent product leaching characteristics, new qualitative and quantitative leaching models have recent $1 \mathrm{y}$ been proposed. 1

The leaching of the waste glass can be described as a 3-stage corrosion process with the third stage involving formation of a protective surface layer. ${ }^{I}$ This layer is formed primarily from the nonradioactive components of the waste. As these species are leached from the glass, they form insoluble compounds at the gel layer which then form the precipitated surface layer. For Savannah River composition 131/TDS waste glass (Table 1), the layer is generally enriched in waste constituents such as $\mathrm{Fe}$ and $\mathrm{Mn}$ and depleted in major frit components such as $\mathrm{Si}$ and $\mathrm{Na}^{2}$ (Table 1). The surface layers as shown in Figure 1 adhere relatively well to the glass underneath and are usually several microns thick. The surface layer thickness decreases and appears more adherent to the glass as the waste content of the glass increases. The thinner surface layers of higher waste-loaded glasses correlate with improved product durability or lower leach rates $^{3}$ (Figure 1).

\section{REPOSITORY SYSTEM TESTS}

After burial in a repository, a new environment is introduced to the product, and the waste form becomes only one element of a multibarrier isolation system. This composite system includes the waste glass form as nucleus surrounded by a casting canister (304L SS), a potential over-pack (possibly a 
titanium-based alloy), potential backfill material (clay), and finally the host repository rock. While there have been experimental studies directed at sorption of radionuclides of interest with the various rock candidates, there have been very few systematic waste form/system interaction experiments performed thus far. As a result, a series of scouting tests were performed to evaluate the separate and synergistic effects that elements of the multibarrier isolation system may have on waste glass durability. These data will be used in conjunction with other studies to define future system tests which can best simulate the most important conditions of the repository and for more detailed analyses. The Repository Systems Program at Savannah River consists of the following elements: (a) static repository tests, (b) slow flow groundwater tests, (c) dynamic leaching experiments, (d) long term leaching tests, and (e) in situ experiments. The scouting tests performed in the static repository program will be summarized and a new dynamic leaching concept will be introduced.

\section{STATIC REPOSITORY TESTS}

- Abbreviated MCC-1 static leaching tests were used in the static repository program. The tests were conducted at $90^{\circ} \mathrm{C}$, for 7 days with deionized water as well as repository groundwaters as leachants. The static repository program consisted of three phases. Phase 1 of the study evaluated the leachability of SRP waste glass leached in the presence of salt, basalt, shale, granite, and tuff at three different ratios of surface areas of sample to volume of leachant $(S A / V)$. These data were then compared to tests on similar glasses leached in the absence of rock. The second phase of this program evaluated the effects of five simulated groundwaters on the leachability of waste glass both with and without host rock present and compared these results to glass leached by deionized water. The groundwaters included many minor as well as major constituents. The third and final phase of the program evaluated waste glass leachability as a function of tests conducted in the presence of candidate canister and overpack metals, backfill mixtures, and five complete package systems. The sample matrices are given in Table 2 and the data are summarized below:

\section{Phase 1 - SA/V and Rock Series}

The concentrations of six different elements of interest found in the deionized water leachate after leaching the waste glass (with and without five 
different rock types) are given in Table 3 as a function of three different $\mathrm{SA} / \mathrm{V}$ ratios. The corresponding "effective leachabilities" (i.e., leachability based on species in solution and not including rock adsorbed species) were then calculated. Following are conclusions drawn from these data:

- The leach rate decreases as $S A / V$ increases for all samples based on mass loss and extraction of nine different elements. This is a beneficial effect for long term repository storage because of the relatively small quantities of water that are anticipated.

- "Effective leachability" generally decreases but only slightly for leaching by deionized water in the presence of rocks (salt, basalt, shale, granite and tuff).

- Leach rates can vary significantly for different elements.

- At a given SA/V ratio, leachability generally correlates well with final pH of the solution. This suggests a non-destructive means for monitoring leachability.

- Leaching in the presence of salt reduces leachability most appreciably, especially at high $S A / V$ ratios. The salt dissolves more readily than any other rock and forms brine which is a less aggressive leachant than deionized water.

- There is no significant difference in the leachability of waste glass when leached in the presence of Carlsbad salt compared to Avery Island salt.

- Key elements found in surface layers such as Fe, Mn, and Mg show very low leach rates for all systems and $S A / V$ ratios studied. This indicates that these elements are also retained in the leached surface layers in these simulated, static repository tests. Therefore, glass leachability in repositories would also be expected to improve with time.

\section{Phase 2 - Groundwater Tests}

Most of the leachability data that now exist are a result of short term leaching tests using deionized water as the leachant. In a repository setting, the most realistic potential leachants are the inherent groundwaters found in the geology. The primary objective of phase 2 of this study was to compare glass leached in the various groundwater compositions with glass leached in deionized water. Furthermore, these data were then compared to leachability results using a rock-equilibrated shale groundwater, "standard" brine and basalt groundwaters used in MCC tests, and an actual shale groundwater extracted from the SRP site. The silicon leachate concentrations are given in Table 4. Following are conclusions from this study: 
- Glass leached in simulated groundwater generally results in a lower leachability than glass leached in deionized water. (This observation is based on silicon extraction after correcting for the initial silicon concentration in the leachant.) Hence, product performance involving groundwaters in a repository should be better than the results from most laboratory tests using deionized water as leachant.

- For leaching of glass using simulated groundwaters in the presence of host rock, the leachability is generally reduced further, although only slightly in most cases.

- The largest reductions in leachability were for brine solutions. The largest source of experimental error was also for salt systems due to the dissolving host rock.

- The simulated shale groundwater was only slightly more aggressive than the actual groundwater and the rock-equilibrated groundwater was the most aggressive leachate used except for deionized water.

- Leachabilities of glass using MCC groundwaters, which incorporate only major elements of the groundwaters, are similar to more complete simulated groundwater compositions. However, this comparison becomes less clear for leaching in the presence of rocks, perhaps due to inherent variations in rock compositions.

\section{Phase 3 - Canister Metals, Backfills, and Complete system Tests}

In phase 3 of the study, a salt repository was selected as an arbitrary reference repository. Each of the potential elements of the multibarrier isolation system was evaluated in the simulated salt environment, including several canister or overpack metal candidates, three backfill mixtures, and three additional "backfill" compositions. A reference "complete system" involving waste glass, a $304 \mathrm{~L}$ stainless steel primary canister metal, a Ticode 12 overpack metal, and a backfill mixture of sand, bentonite and charcoal was then selected for further tests. Each of these complete systems was then leached in the presence of the five different rock geologies of salt, basalt, shale, granite, and tuff. As a result of recent studies performed by $C$. 0 . Buckwalter at Battelle Pacific Northwest Laboratory, a third metal candidate, lead, was also evaluated in a long term leachability experiment. These data are sumarized in Table 5, and following are conclusions from this study:

- In system tests involving waste glass, canister material, overpack metal, backfill, and five different rock types, the backfill constituent most strongly influenced the release rate of species of interest. 
- Backfill can be beneficial, marginal, or perhaps detrimental to the release rate of species of interest depending on the choice of material.

- Waste glass release rates are significantly lowered in the presence of lead.

\section{DYNAMIC REPOSITORY TESTS}

An important consideration for burial of waste glass forms in a repositoryenvironment is the potential effect of groundwater flowrates on glass durability. In order to investigate this effect, a dynamic leaching test station has recently been developed and placed into operation at Savannah River. The station consists of a series of Teflon (trademark of Du Pont) modular units which can contain the various elements of the multibarrier isolation system. All units are located in a large oven in which the atmosphere is controlled and the temperature held constant to $\pm 2^{\circ} \mathrm{C}$. A variety of potential leachants including simulated groundwaters are being used in this system which can be operated in a single pass or recirculating manner (Figure 2). Preliminary analysis of this system shows that only small changes in leachability of waste glass forms occurred even under very high flow rates. A more comprehensive testing program is now in progress.

\section{ACRNOWLEDGEMENT}

The information contained in this article was developed during the course of work under Contract No. DE-AC09-76SR00001 with the U.S. Department of Energy.

\section{REFERENCES}

1. Wicks, G. F. and Wallace, R. M., "Leachability of Waste Glass Systems - Physical and Mathematical Models," to be published in Journal of Nuclear Materials; Leaching Chemistry of Defense Borosilicate Glass, to be presented at the Sixth International symposium on the Scientific Basis for Nuclear Waste Management, Boston, Mass., November 1982.

2. Wicks, G. G., Mosley, W. C., Whitkop, P. G. and Saturday, K. A., "Durability of Simulated Waste Glass - Effects of Pressure and Formation of Surface Layers," to be published in Journal of Non-Crystalline Solids.

3. Rankin, W. D. and Wicks, G. G., "The Chemical Durability of Savannah River Plant Waste Glass as a Function of Waste Loading," to be presented at the 84 th Annual Meeting and Fxposition of the American Ceramic Society, Cincinnati, Ohio, May 1982. 
Table 1. SIMULATED 131/TDS WASTE GLASS COMPOSITION

COMPONENT 131 FRIT $(w t \%) \quad$ COMPONENT TIS WASTF (wt \%)

\begin{tabular}{|c|c|c|c|}
\hline $\mathrm{SiO}_{2}$ & 39.5 & $\mathrm{SiO}_{2}$ & 1.2 \\
\hline $\mathrm{Na}_{2} \mathrm{O}$ & 12.1 & $\mathrm{Na}_{2} \mathrm{n}$ & 0.9 \\
\hline $\mathrm{B}_{2} \mathrm{O}_{3}$ & 10.0 & $\mathrm{CsCl}$ & $1 . n$ \\
\hline $\mathrm{Tin}_{2}$ & 0.7 & $\mathrm{SrCl}_{2}$ & $1 . n$ \\
\hline $\mathrm{Li}_{2}{ }^{\mathrm{O}}$ & 3.9 & $\mathrm{Fe}_{2} \mathrm{O}_{3}$ & 14.1 \\
\hline $\mathrm{MgO}$ & 1.4 & $\mathrm{MnO}_{2}$ & 4.1 \\
\hline $\mathrm{ZrO}_{2}$ & 0.3 & $\mathrm{Al}_{2} \mathrm{O}_{3}$ & 2.8 \\
\hline \multirow[t]{5}{*}{$\mathrm{La}_{2} \mathrm{O}_{3}$} & 0.3 & $\mathrm{NiO}$ & 1.7 \\
\hline & & Can & 1.1 \\
\hline & & $\mathrm{Na}_{2} \mathrm{SO}_{4}$ & 0.2 \\
\hline & & COAI. & 0.7 \\
\hline & & $A W-500 *$ & 3.0 \\
\hline
\end{tabular}

* Linde AW-500 zeolite (calcium-aluminum-silicate).

TABLE 2. STATIC REPOSITORY TESTS SAMPLE MATRICES

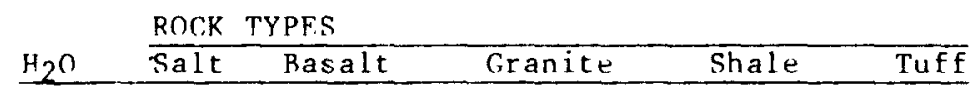

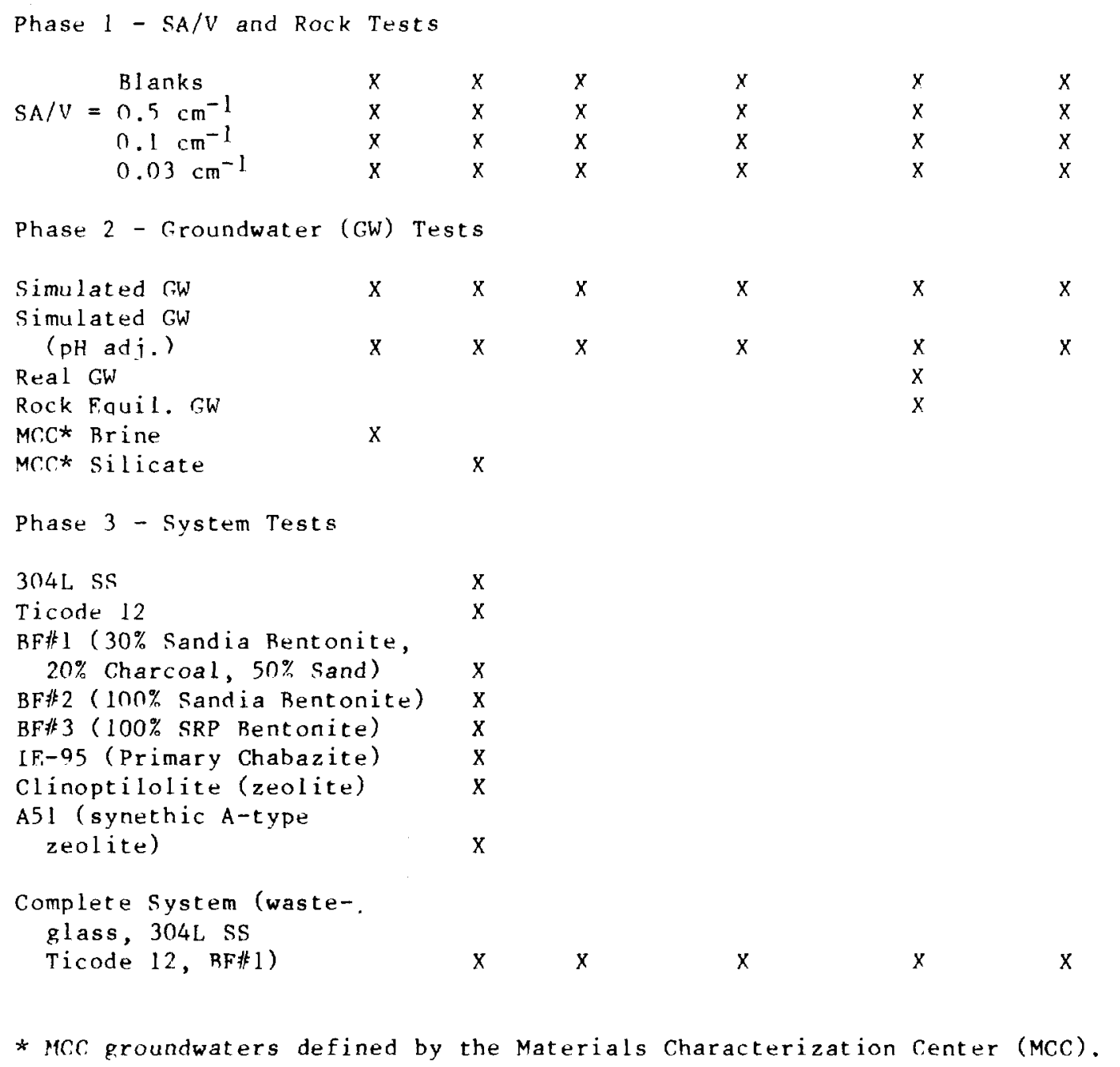




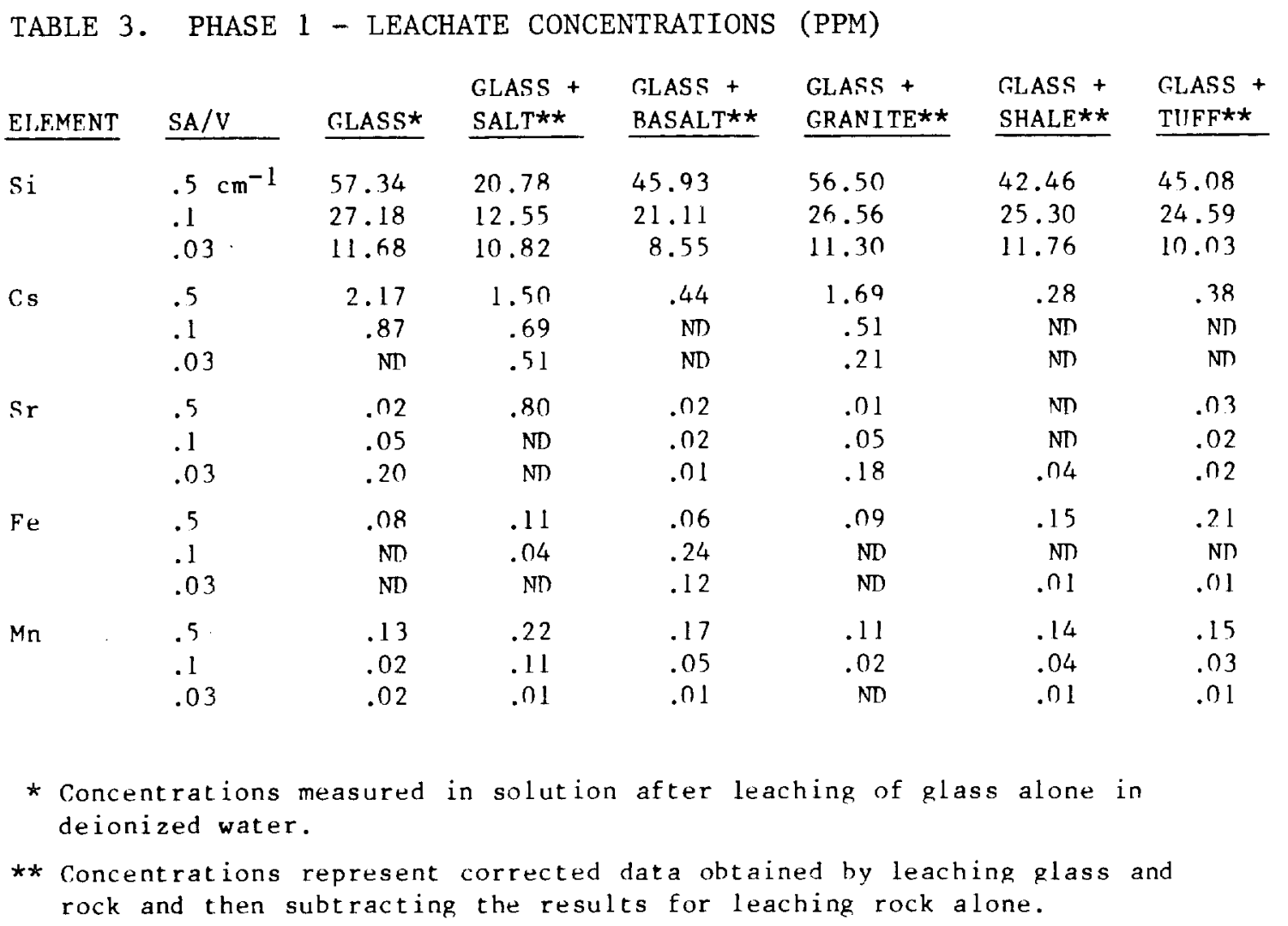

TABLE 4. PHASE 2 - Si LEACHATE CONCENTRATIONS (PPM)

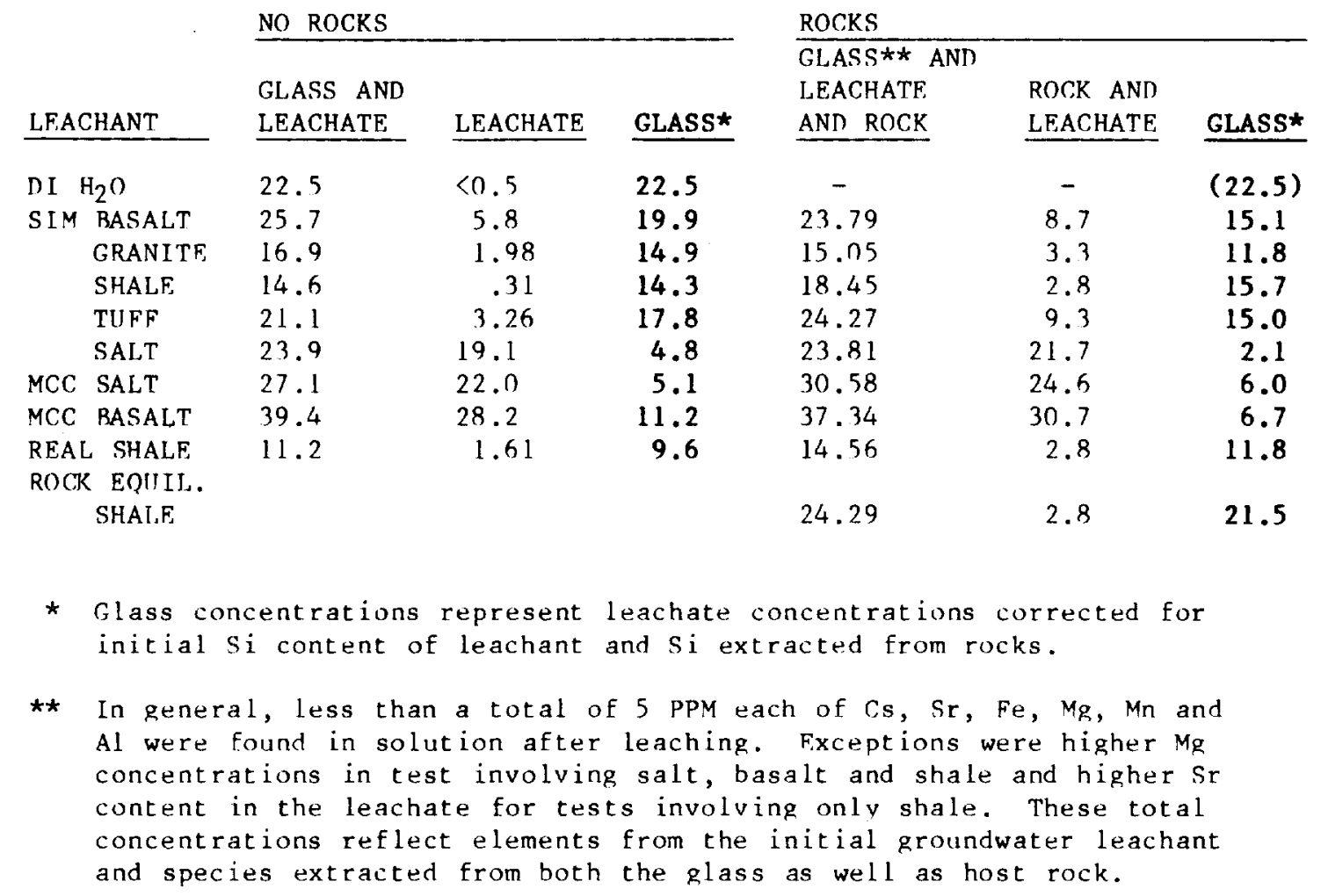


TABLE 5. PHASE 3 - MEASURED CONCENTRATIONS IN PPM (UNCORR.)*

\begin{tabular}{|c|c|c|c|c|c|c|}
\hline ROCK & $\begin{array}{l}\text { CANISTER } \\
\text { MATER IAL } \\
\end{array}$ & BACKFILL & $\underline{\mathrm{Si}}$ & $\mathrm{Cs}$ & $\underline{\mathrm{Sr}}$ & $\begin{array}{l}\text { FINAL } \\
\mathrm{pH}\end{array}$ \\
\hline GIASS ALONE & - & - & 27.31 & .969 & .05 & 9.59 \\
\hline GIJASS ALONE** & $\mathrm{Pb}$ & - & 0.64 & & .007 & \\
\hline SALT & - & - & 15.15 & .918 & 1.35 & 9.25 \\
\hline SALT & $3 \cap 4 \mathrm{~L}$ & - & 20.00 & .822 & .68 & 9.21 \\
\hline & Ticode & - & 18.50 & .756 & .52 & 9.35 \\
\hline SAI.T & - & BF 1 & 39.5 & .264 & 1.47 & 8.44 \\
\hline & - & $\mathrm{BF} 2$ & 52.5 & .094 & 3.33 & 8.43 \\
\hline & - & BF 3 & 24.3 & .390 & 2.76 & 8.24 \\
\hline SAI,T & - & IE 95 & 36.6 & .043 & 4.17 & 7.43 \\
\hline & - & CLINO & 53.2 & .109 & .95 & 6.55 \\
\hline & - & $A-51$ & 24.3 & .361 & .04 & 7.80 \\
\hline SALT & $\begin{array}{l}304 \mathrm{~L} \\
\text { Ticode } 12\end{array}$ & RF 1 & 30.00 & .333 & 1.46 & 8.33 \\
\hline A. I. SALT & $\begin{array}{l}304 \mathrm{~L} \\
\text { Ticode } 12\end{array}$ & $\mathrm{RF} \quad \mathrm{I}$ & 31.00 & .456 & 1.30 & 8.23 \\
\hline BASALT & $\begin{array}{l}304 \mathrm{~L} \\
\text { Ticode } 12\end{array}$ & BF 1 & 62.3 & .037 & .18 & 9.22 \\
\hline GRANITE & $\begin{array}{l}304 \mathrm{~L} \\
\text { Ticode } 12\end{array}$ & BF 1 & 72.7 & .053 & .17 & 9.31 \\
\hline SHALF, & $\begin{array}{l}304 \mathrm{~L} \\
\text { Ticode } 12\end{array}$ & RF 1 & 112.0 & .045 & .40 & 9.23 \\
\hline TIIFF & $\begin{array}{l}304 \mathrm{~L} \\
\text { Ticode } 12\end{array}$ & RF 1 & $86 . \cap$ & .069 & .23 & 9.18 \\
\hline
\end{tabular}

* All tests conducted with $131 /$ TDS-3A waste glass. Concentrations represent total concentrations measured in solution, not corrected for leaching from multibarrier elements such as backfill materials.

** Modified MCC-1 test, $90^{\circ} \mathrm{C} 11-1 / 2$ months, $S A / V=0.1 \mathrm{~cm}^{-1}$. All other tests conducted under similar conditions except for 7 days in duration. 


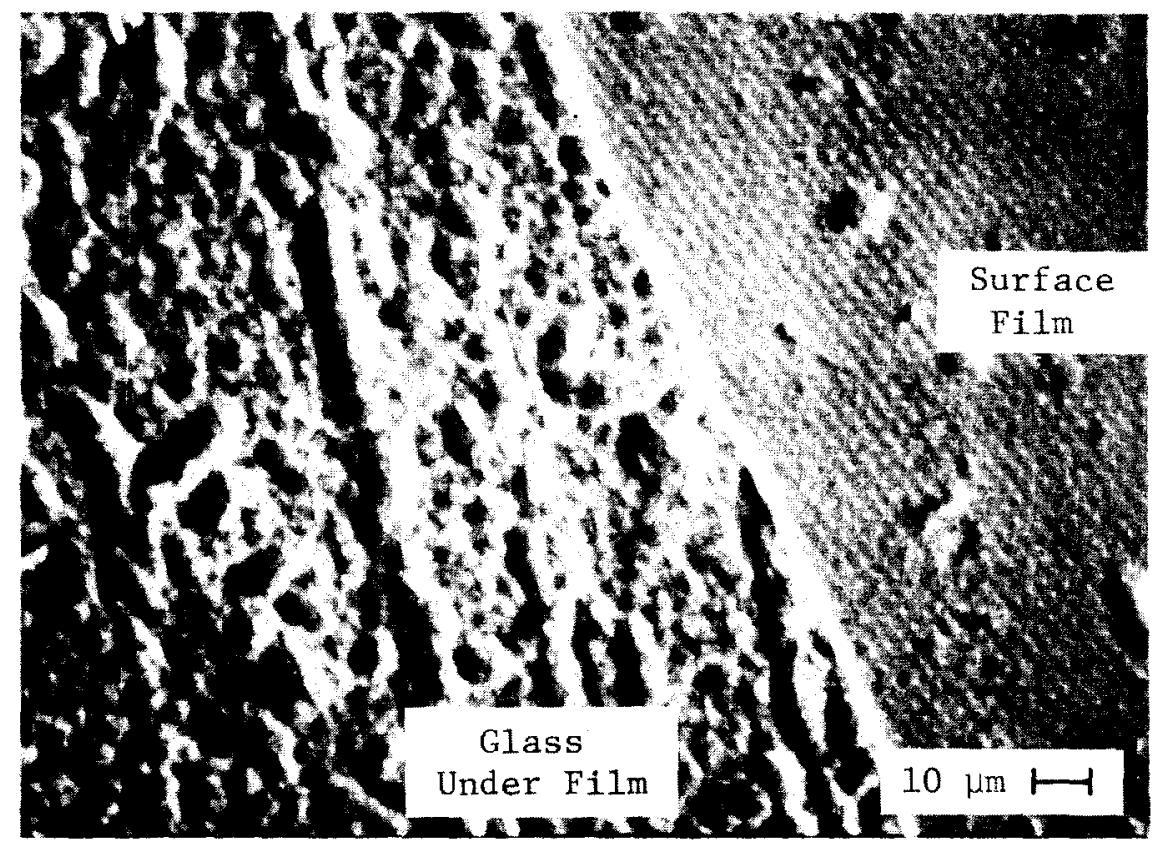

A. Top view of surface layer and glass underneath

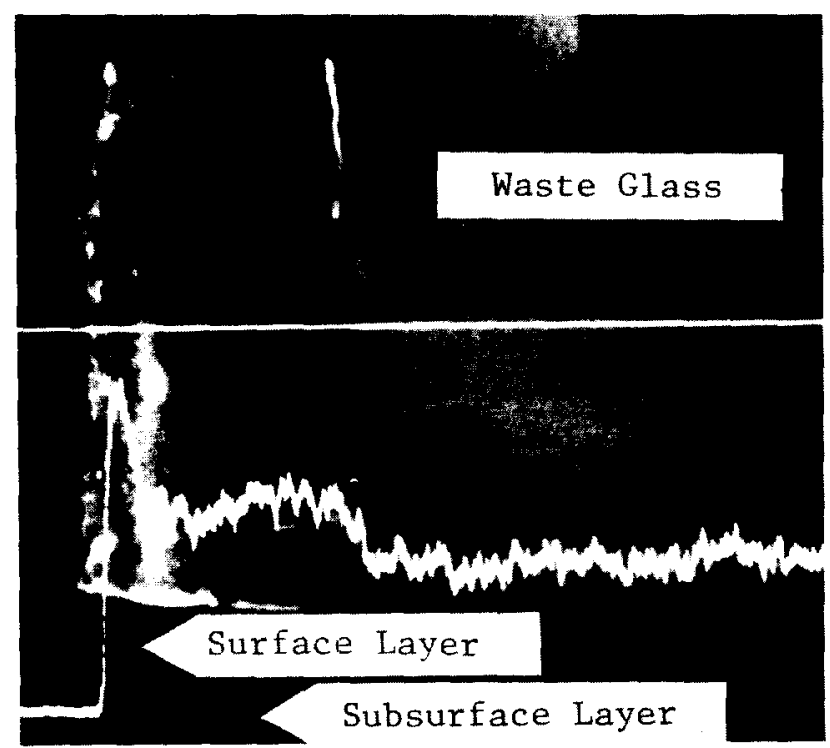

20 wt\% Waste

$5 \mu \mathrm{m} \longmapsto$

$\mathrm{L}(\operatorname{mass} 10 \mathrm{ss})=1.19 \mathrm{~g} /\left(\mathrm{m}^{2}-\right.$ day $)$
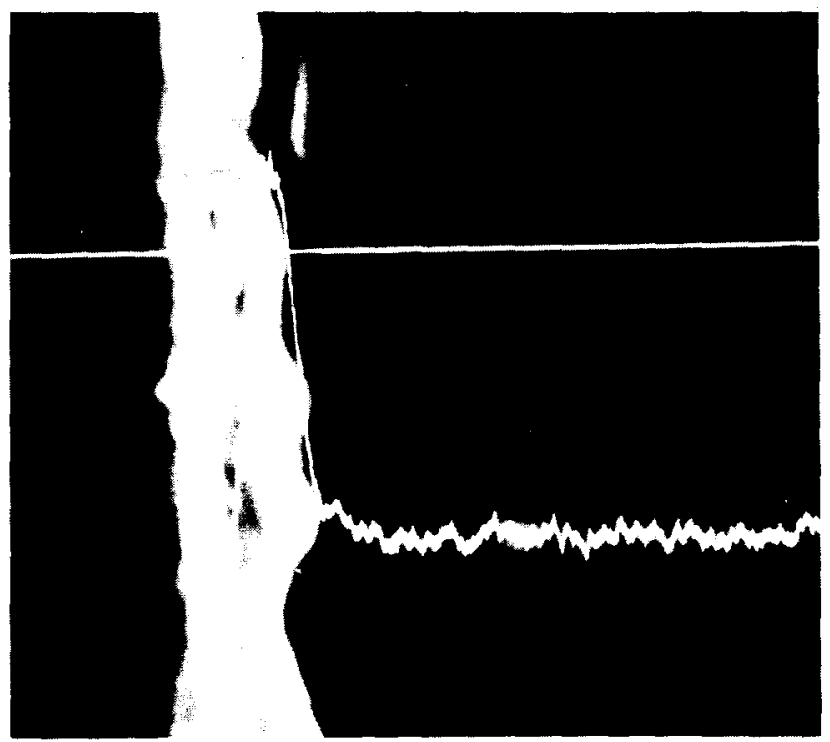

$30 \mathrm{wt} \%$ Waste

$2 \mu \mathrm{m} \longmapsto$

$\mathrm{L}($ mass loss $)=0.51 \mathrm{~g} /\left(\mathrm{m}^{2}\right.$-day $)$

B. Cross sections of leached layers for $20 \%$ and $30 \%$ waste loaded glasses with $x$-ray line profiles of waste constituent $\mathrm{Fe}$.

FIGURE 1 Leached Glass Surface Layers 


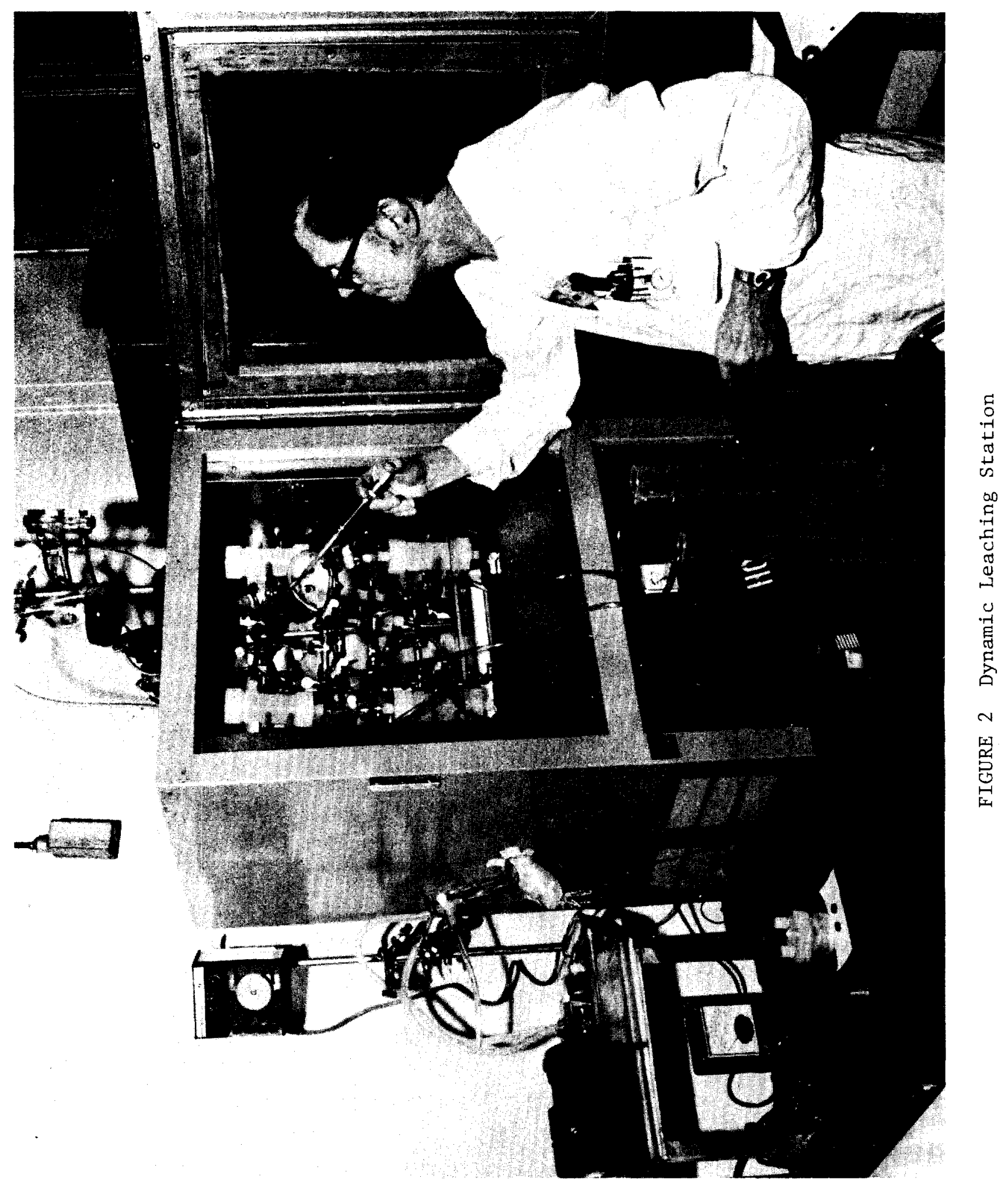

